\title{
SIMULASI PERAMBATAN GELOMBANG ELEKTROMAGNETIK PADA KRISTAL FOTONIK 2D MENGGUNAKAN METODE FINITE DIFFERENCE FREQUENCY DOMAIN
}

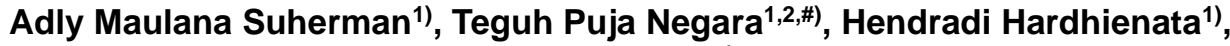 \\ Husin Alatas ${ }^{1)}$ \\ 1)Program Studi Fisika, FMIPA, Institut Pertanian Bogor \\ 2)Program Studi Ilmu Komputer, FMIPA, Universitas Pakuan, Bogor, Indonesia \\ \#Corresponding Author: teguhpuja795@gmail.com
}

Article history: received 27 February 2019; revised 25 May 2019; accepted 10 June 2019

\begin{abstract}
Abstrak
Simulasi numerik pada kristal fotonik dua dimensi dengan cacat dianalisis menggunakan Finite Difference Frequency Domain (FDFD). Pendekatan ini terdiri dari formulasi Maxwell yang menggunakan Central Finite Difference untuk meletakkan medan dan material pada titik-titik diskrit grid Yee, sehingga diperoleh persamaan gelombang matriks dalam bentuk vektor kolom. Kondisi batas penyerap meggunakan Perfectly Matched Layer (PML) dengan konduktivitas magnetik fiktif untuk meluruhkan gelombang yang masuk di tepi perhitungan domain. Kristal fotonik dapat diasumsikan sebagai kisi periodik dari material dielektrik yang menghasillkan fenomena photonic band gap (PBG).. Hasil simulasi FDFD dibandingkan dengan literatur dengan selisih sebesar 0,056. Nilai selisih yang kecil ini diartikan metode ini cukup baik untuk menganalisis fenomena PBG. Untuk defek titik dan akumulasi gelombang elektromagnetik cacat linier diselidiki dan dianalisis dengan respons spektra. Penyisipan cacat pada kristal fotonik akan menghasilkan photonic pass band (PPB). Hasil simulasi menunjukkan PPB bergantung pada vektor sudut datang, permitivitas material, dan lebar struktur cacat.
\end{abstract}

Kata kunci: kristal fotonik, metode finite difference frequency domain, celah pita fotonik, lapisan yang sangat cocok

\begin{abstract}
Numerical simulations on two-dimensional photonic crystals with defects were analyzed using the Finite Difference Frequency Domain (FDFD). This approach consists of Maxwell's formulation that uses Central Finite Difference to place fields and materials at discrete points of the Yee grid, so that the matrix wave equation is obtained in the form of column vectors. Absorbent boundary conditions use Perfectly Matched Layer (PML) with fictitious magnetic conductivity to shed incoming waves at the edge of the domain calculation. Photonic crystals can be assumed to be a periodic lattice of dielectric material that produces the phenomenon of photonic band gap (PBG). The results of FDFD simulations are compared with the literature with a difference of 0.056. This small difference value means that this method is good enough to analyze PBG phenomena. For point defects and the accumulation of electromagnetic waves, linear defects are investigated and analyzed with spectral responses. Insertion of defects in photonic crystals will produce a photonic pass band (PPB). The simulation results show that $P P B$ depends on the angle of arrival vector, material permittivity, and width of the defect structure.
\end{abstract}

Keywords: kristal fotonik, metode finite difference frequency domain, photonic bandgap, perfectly matched layer 


\section{Pendahuluan}

Teknologi optik memiliki perkembangan yang cukup massif dibandingkan dengan teknologi elektronik, terbukti banyak fenomena optik yang belum dimanfaatkan untuk teknologi optik. Salah satu penyebabnya adalah modeling (pemecahan dengan solusi matematik) yang merupakan tahap awal sebelum fabrikasi mensyaratkan perangkat matematika yang cukup kuat dan penyediaan komputasi yang optimal agar dapat mengungkap fenomena optik yang dapat diarahkan untuk piranti optik [1]. Interaksi cahaya terhadap struktur dapat dianalisis secara numerik menggunakan "bentuk kuat" dan "bentuk lemah" untuk menjelaskan fenomena yang terjadi dan penerapannya dalam bidang optik [2]. "Bentuk lemah" dalam simulasi numerik dikenal dengan metode Finite Difference (beda hingga) yang solusinya menggunakan bentuk differensial. Metode Beda-Hingga dikembangkan untuk ranah waktu yang dikenal dengan Finite Difference Time Domain (FDTD) pertama kali dilakukan oleh Yee tahun 1966 untuk permasalahn listrik-magnet [3]. Metode ini kemudian diterapkan untuk analisa antenna, planar circuit, penginderaan jarak jauh, biomedis, dan lain. Tahun 1996, Algoritma Yee dikembangkan oleh Lui dan Cheng untuk Metode Beda-Hingga untuk ranah frekuensi dikenal dengan Finite Difference Frequensi Domain (FDFD) [4]. Penggunaan FDFD lebih menguntungkan pada medan microwave karena beberapa alasan. Pertama, semua material memiliki permitivitas dan permeabilitas kompleks yang bergantung pada frekuensi. Kedua, metode ini dapat mensimulasikan medan listrik dan magnet pada struktur yang dapat diubah-ubah. Ketiga, kesesuaian dengan konsep yang cenderung pada penurunan secara langsung pada matriks hamburan [5]. Keempat, FDFD bekerja beberapa menit sedangkan simulasi dengan FDTD bekerja beberapa jam. Penggunaan metode FDFD telah banyak dilakukan, seperti analisis relasi dispersi pada struktur pandu gelombang, pemodelan struktur microstrip, analisis photonic band-gap, dan lain-lain.

Pada penelitian ini analisis perambatan gelombang elektromagnetik pada struktur kristal fononik dua dimensi dilakukan dengan menggunakan metode FDFD. Analisis struktur tanpa cacatt dan dengan cacat dilakukan untuk melihat PBG dan PPB pada range frekuensi tertentu sebagai dasar fabrikasi waveguide atau sensor

\section{Metode Penelitian}

Metode yang digunakan dalam penelitian ini adalah metode beda hingga ranah frekuensi (finite difference frequency domain) yang diturunkan dari 4 persamaan Maxwell [6]. Metode Finite Difference Frequency Domain (FDFD) adalah solusi numerik untuk permasalahan elektromagnetik dan akustik, berbasis pada aproksimasi Finite Difference pada turunan operator persamaan differensial yang akan dipecahkan. Metode ini dapat diaplikasikan pada struktur dengan panjang skala berapapun dan untuk frekuensi radiasi gelombang elektromagnetik (EM) berapapun [7]. Dibandingkan metode FDTD, metode FDFD lebih sederhana untuk solusi keadaan tetap (steady-state) dan solusinya bekerja lebih cepat [8]. Akan tetapi, metode FDFD tidak poluler karena konvergensinya lambat untuk persamaan Maxwell 3D. Persamaan untuk metode FDFD diturunkan dari persamaan Maxwell, yaitu:

$$
\begin{gathered}
\nabla \times \bar{E}=k_{0} \mu \bar{H} \\
\nabla \times \bar{H}=k_{0} \varepsilon \bar{E} \\
\text { Dimana } \bar{H}=j \sqrt{\frac{\varepsilon_{0}}{\mu_{0}} H \text { dan } \quad k_{0}=\omega \sqrt{\mu_{0} \varepsilon_{0}}} \cdot \quad \text { Normalisasi } \quad \text { grid } \quad x^{\prime}=k_{0} x \text { dan } \\
\varepsilon_{x y}=\varepsilon_{x z}=\varepsilon_{y x}=\varepsilon_{y z}=\varepsilon_{z x}=\varepsilon_{z y}=0 .
\end{gathered}
$$

Diskritsasi persamaan Maxwell untuk mode TE dapat ditulis:

$$
\frac{\partial \bar{E}_{y}}{\partial x^{\prime}}-\frac{\partial \bar{E}_{x}}{\partial y^{\prime}}=\frac{\bar{E}_{y}^{i+1, j}-\bar{E}_{y}^{i, j}}{\Delta x^{\prime}}-\frac{\bar{E}_{x}^{i, j+1}-\bar{E}_{x}^{i, j}}{\Delta y^{\prime}}=\mu_{z z} H_{z}^{i, j}
$$




$$
\begin{gathered}
\frac{\partial \bar{H}_{z}}{\partial y^{\prime}}=\frac{\bar{H}_{z}^{i, j}-\bar{H}_{z}^{i, j-1}}{\Delta y^{\prime}}=\varepsilon_{x x} E_{x}^{i, j} \\
-\frac{\partial \bar{H}_{z}}{\partial x^{\prime}}=-\frac{\bar{H}_{z}^{i, j}-\bar{H}_{z}^{i-1, j}}{\Delta x^{\prime}}=\varepsilon_{y y} E_{y}^{i, j}
\end{gathered}
$$

Persamaan diskritasi tersebut dapat dibentuk menjadi persamaan Eigen.

$$
k_{0}{ }^{2} \bar{H}_{z}=\left\{\varepsilon_{12}{ }^{-1} U_{1} \varepsilon_{33}{ }^{-1} V_{2}-\varepsilon_{22}{ }^{-1} U_{1} \varepsilon_{33}{ }^{-1} V_{1}\right\} \bar{H}_{z}
$$

Dengan menerapkan kondisi batas Bloch dapat digunakan untuk mendapatkan matriks $U$ dan $V$. Persamaan tersebut dapat ditulis::

$$
A_{H} H_{Z}=0
$$
persamaan:

Matriks masking dapat dilihat pada [7] dapat sedikit dimodifikasi dan dibentuk dari

$$
\mathbf{Q}=\left(\begin{array}{ccc}
Q_{x} & 0 & 0 \\
0 & Q_{y} & 0 \\
0 & 0 & Q_{z}
\end{array}\right)
$$

Persamaan tersebut merupakan matriks blok diagonal yang terdiri atas: $Q_{x}$ medan yang dihamburkan dari $E_{x}, Q_{y}$ medan yang dihamburkan dari $E_{y}$, dan $Q_{z}$ medan yang dihamburkan $E_{z}$.

Jika diketahui matriks $A$, sumber medan $f_{s r c}$, dan matriks masking $Q$, vektor sumber f , dihitung sesuai dengan persamaan:

$$
\mathbf{A}_{H}=\mathbf{D}_{x}^{E}{ }^{E} \varepsilon_{y y}^{-1} \mathbf{D}_{x}^{H}+\mathbf{D}_{y}^{E}{ }_{,}^{E} \varepsilon_{x x}^{-1} \mathbf{D}_{y^{\prime}}^{H}+\mu_{z z}
$$

Matriks merupakan solusi persamaan Eigen dari persamaan (9). Untuk polarisasi TE dan TM dapat dinyatakan secara berturut-turut:

Transmittansi untuk polarisasi TE dan TM dapat ditulis secara berturut-turut:

$$
T_{H}(m)=\left|S_{t r n}(m)\right|^{2} \cdot\left[\frac{k_{z, m}^{t r n}}{k_{z}^{\text {inc }}} \frac{\varepsilon_{r e f}}{\varepsilon_{t r n}}\right]
$$

Disain struktur kristal fotonik dalam penelitian ini mengikuti gambar 7. Struktur terdiri atas susunan rod sepanjang sumbu $x$ dan $y$, sedangkan vektor gelombang $\vec{k}$ datang dari ara $y$. Pada sumbu susunan rod diasumsikan infinite dengan dibatasi kondisi batas periodik (PBC) dan pada tepi sumbu dipasang medium penyerap berupa PML agar gelombang yang datang tidak mengganggu wilayah analisa. Panjang dan lebar struktur berturut-turut $2.66 \mu \mathrm{m}$ dan $6.79 \mu \mathrm{m}$. Rod memiliki permitivitas $\varepsilon=11.4$ dengan periodisitas $0.533 \mu \mathrm{m}$ 

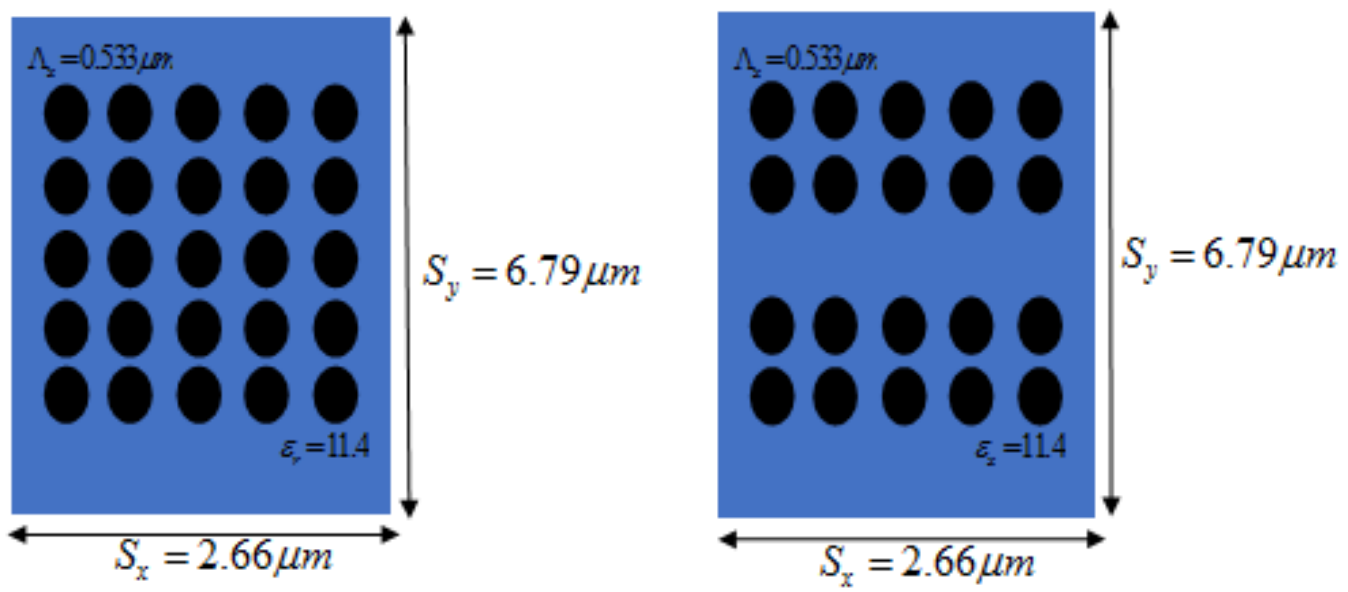

Gambar 8. Disain struktur kristal fotonik rod tanpa defek dan dengan defek baris

Bahasa pemrograman yang dibutuhkan pada penelitian ini adalah Matlab. Sintaks ditulis sesuai dengan perumusan FDFD dan dilakuan análisis terhadap bebepa variasi struktur seperti variasi defek pada struktur kristal fotonik.

Tabel 1. Parameter Kristal fotonik

\begin{tabular}{clc}
\hline No & \multicolumn{1}{c}{ Parameter } & Nilai \\
\hline 1 & Panjang gelombang & $1-2.5 \mu \mathrm{m}$ \\
2 & Panjang dan lebar wilayah analisa & $6.79 \mu \mathrm{m}$ dan $2.66 \mu \mathrm{m}$ \\
3 & Panjang dan lebar struktur & $4.79 \mu \mathrm{m}$ dan $2.66 \mu \mathrm{m}$ \\
4 & Indeks bias substrat & 1 \\
5 & Indeks bias rod & 3.43 \\
6 & Ukuran grid & $270 \times 279$ \\
7 & Ukuran PML & 30 \\
8 & Ukuran Buffer & 1 \\
\hline
\end{tabular}

\section{Hasil dan Pembahasan}

Uji coba validasi untuk perumusan FDFD dalam program, dilakukan simulasi gelombang elektromagnetik mode TM yang merambat di udara sebagaimana pada gambar 1(a). Gelombang elektromagnetik tersebut menjalar sepanjang sumbu $y$ dan homogen disepanjang $x$ dari struktur kristal fotonik. Amplitudo dalam simulasi ini benilai 1, panjang gelombang di set dari 1000 sampai $2500 \mathrm{~nm}$. Medium penyerap digunakan agar tidak terjadinya pemantulan yang dapat mengganggu perhitungan pada domain komputasi, resolusi grid harus cukup kecil guna membangun struktur kristal fotonik secara akurat, yaitu dengan memilih $\lambda_{\min } / 20$.

Hasil running simulasi pada kasus gelombang menjalar pada medium udara transmitansinya akan bernilai sempurna gambar 1(b), ini bisa diartikan bahwa medium penyerap PML bekerja dengan cukup baik sehingga tidak mengganggu wilayah analisa. Pengaturan panjang gelombang disapu dari 1000 hingga $2500 \mathrm{~nm}$ untuk mendapatkan nilai band gap pada selang panjang gelombang telekomunikasi optik. 

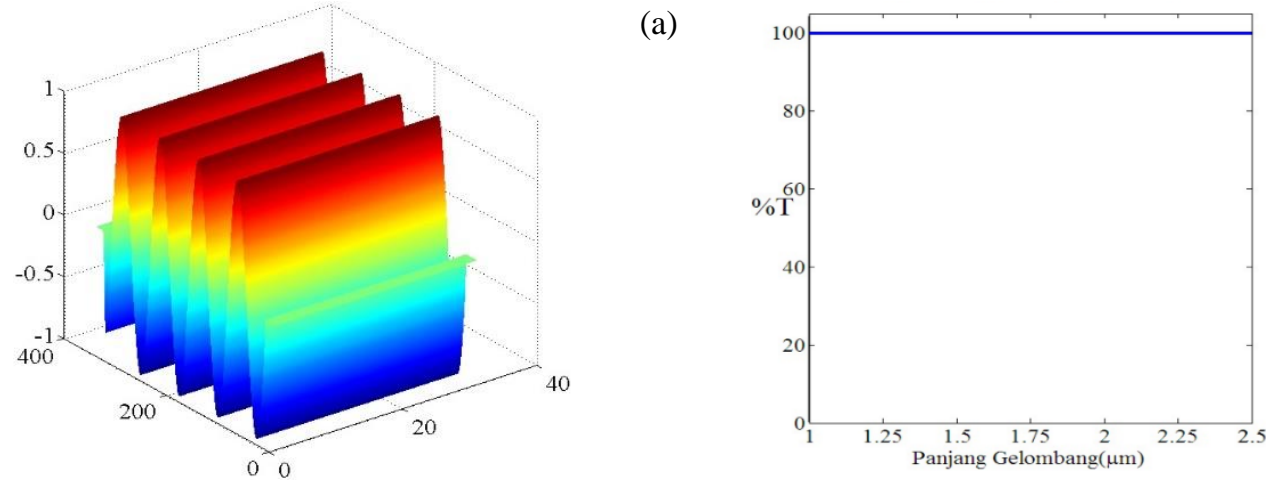

(b)

Gambar 1. (a) Profil mode transversal magnetic (TM) dari gelombang elektomagnet menjalar disepanjang medium udara (b) Spektra transmitansi pada medium permitivitas $\varepsilon_{b}=1$.

Perambatan gelombang elektromagnetik dalam struktur kristal fotonik tanpa defek dapat disimulasikan dengan Matlab untuk range frekuensi 1 sampai $2.5 \mu \mathrm{m}$. Terlihat dari hasil simulasi, gelombang tidak dapat berpropagasi dan melemah pada selang panjang gelombang 1.262 sampai $2.104 \mu m$ (gambar 2(b)), selang panjang gelombang tersebut dikenal dengan photonicband gap (PBG), dalam rentang band gap yang di dapatkan, terlihat lebar pita sangatlah lebar jika dibandingkan dengan panjang gelombang yang beroperasi dalam saluran komunikasi optik (seperti silikon fiber) sebesar $1.5 \mu \mathrm{m}$.

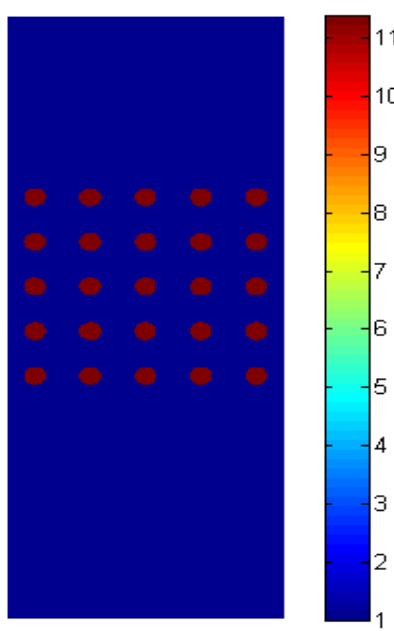

(a)

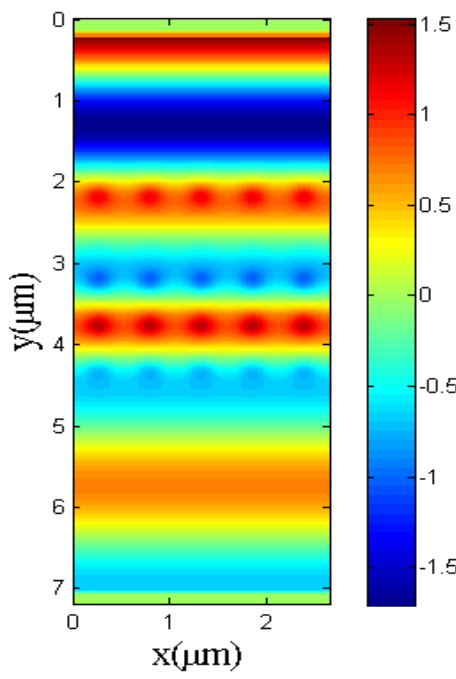

(b)

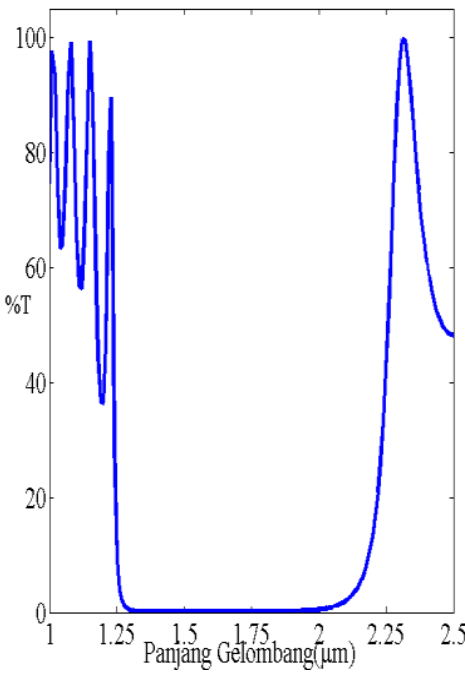

(c)

Gambar 2. (a) Stuktur kristal fotonik tanpa defek (b) Perambatan gelombang dalam struktur tanpa defek (c) Spektra transmitansi pada medium

Jika rentang panjang gelombang dalam simulasi dimasukkan ke dalam persamaan $\omega a / 2 \pi c$, maka didapatkan hasil rentang PBG pada panjang gelombang $1.262 \mu m$ adalah $0.422 \mu \mathrm{m}$. Tetapi, pada panjang geombang $2.307 \mu \mathrm{m}$ didapatkan hasil rentang PBG sebesar $0.231 \mu \mathrm{m}$. Nilai ini memiliki selisih $0.56 \mu \mathrm{m}$ dari literatur PBG pita pertama yaitu $0.287 \mu \mathrm{m}$

Berdasarkan penelitian sebelumnya, range panjang gelombang band gap dapat digeser sesuai dengan sudut datang dari panjang gelombang input dan ripple (side lobe) dapat diatur dengan variasi indeks bias rod 


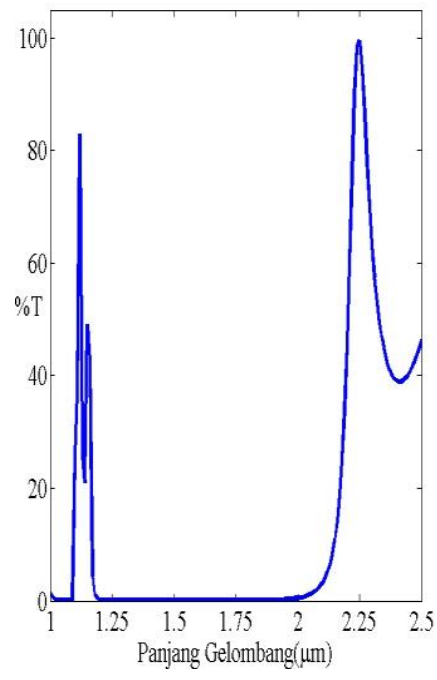

(a)

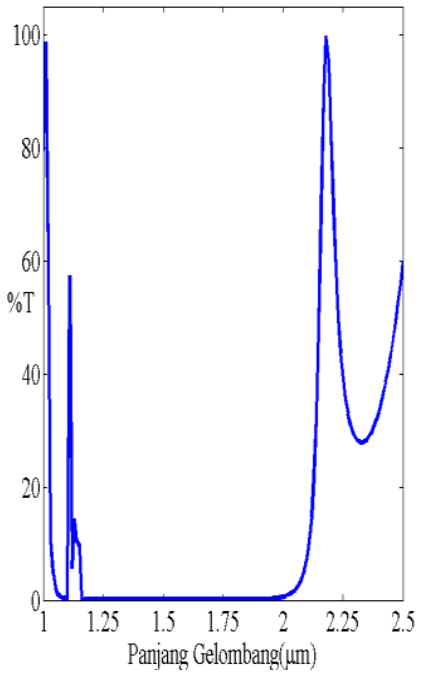

(b)

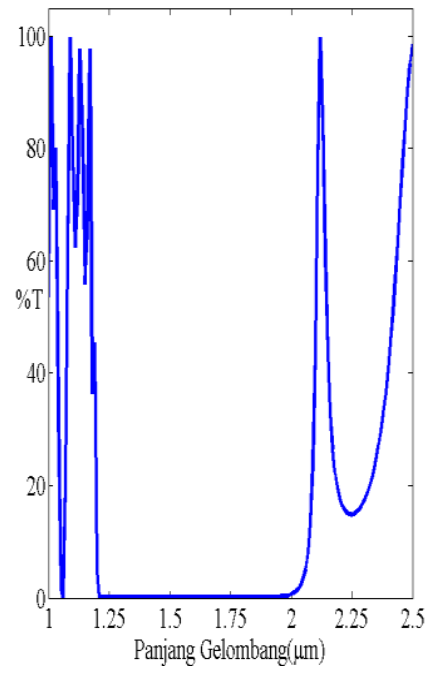

(c)

Gambar 3. Pergeseran range panjang gelombang band gap dengan sudut datang

$$
\text { (a) } 30^{\circ} \text { (b) } 45^{\circ} \text { dan (c) } 60^{\circ}
$$

Pergeseran range panjang gelombang band gap karena variasi sudut datang ditunjukkan oleh gambar. Terlihat bahwa semakin besar sudut datang maka band gap akan semakin bergeser ke kiri (gambar (3)).

Sebuah cacat dapat menyebabkan ketidak sempurnaan dari struktur PhC. Dalam kasus defek titik akan dilakukan eliminasi sebuah dieletrik rod yang ditunjukan dalam Gambar 4 (a).

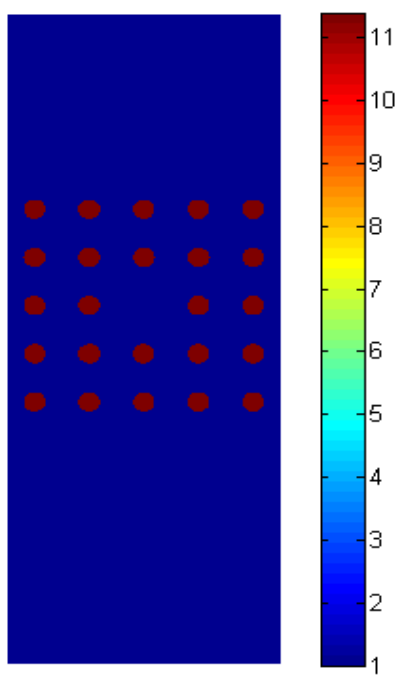

(a)

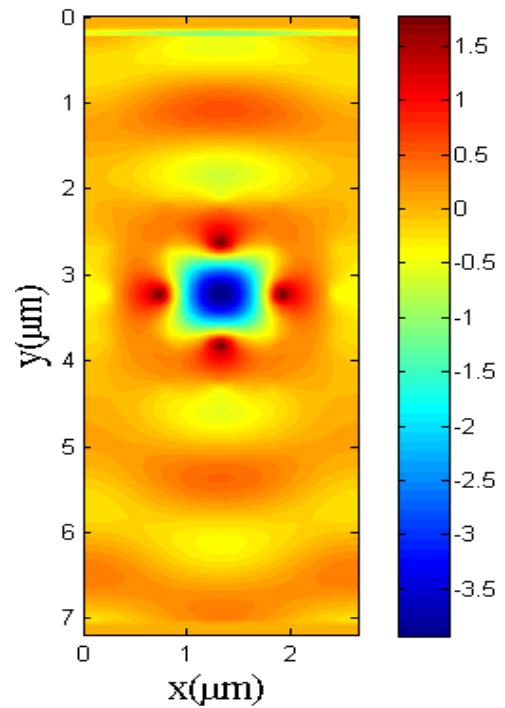

(b)

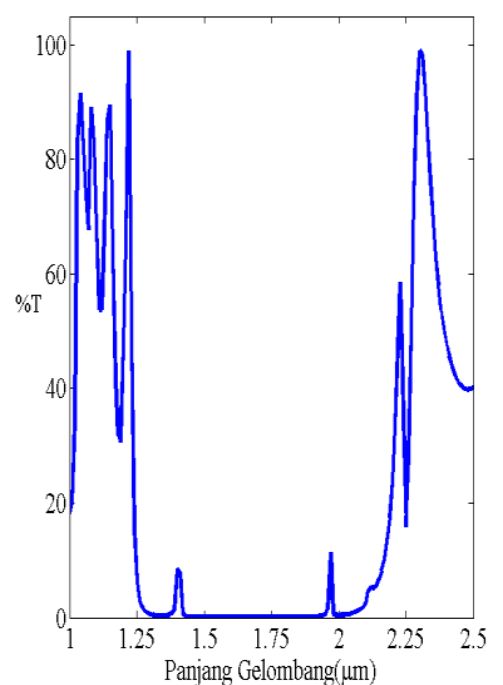

(c)

Gambar 3. (a) Stuktur kristal fotonik dengan defek titik (b) Perambatan gelombang dalam struktur pada $\lambda=1.4 \mu m$ (c) Spektra transmitansi pada struktur

Berdasarkan hasil simulasi terlihat bahwa medan terperangkap dalam defek dan mengalami penguatan medan yang kecil di dalam range band gap pada panjang gelombang $\lambda=1.4 \mu \mathrm{m}$ dan $\lambda=1.9 \mu \mathrm{m}$. Variasi nilai indeks bias rod dapat mempengaruhi penguatan medan pada defek

Untuk kasus defek baris, rod dapat dihilangkan sepanjang salah satu baris sehingga terbenuk kanal arah sumbu-y. Terjadi mode resonansi yang kuat di dalam range panjang 
KOMPUTASI (Jurnal IImiah IImu Komputer dan Matematika)

Vol. 16, No. 2, Juli 2019, Hal. $255-262$

P-ISSN: 1693-7554, E-ISSN: 2654-3990

gelombang band gap ditandai dengan munculnya pita tansmitansi 100\% dalam PBG yang disebut photonic pass band (PPB)

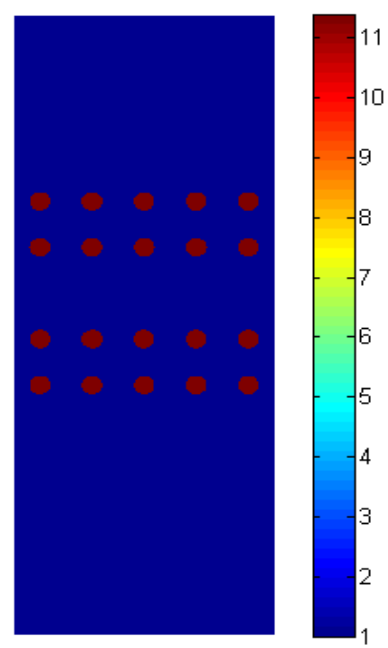

(a)

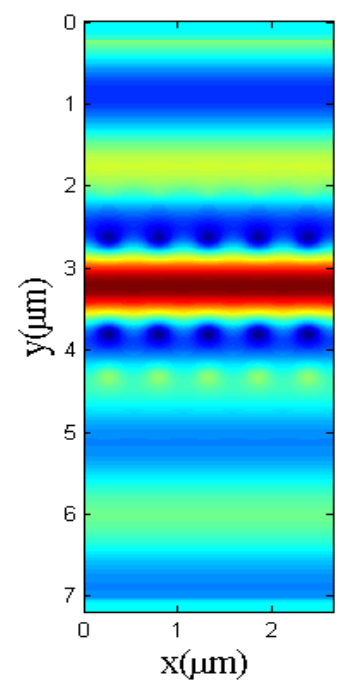

(b)

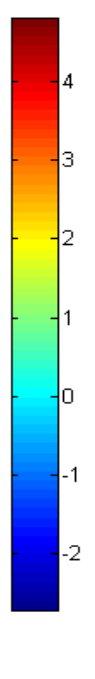

Gambar 4. (a) Stuktur kristal fotonik dengan defek baris (b) Perambatan gelombang

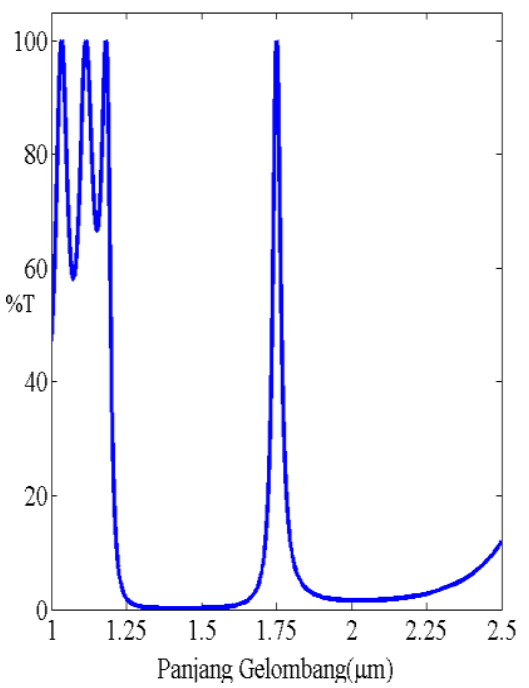

(c) dalam struktur pada $\lambda=1.4 \mu \mathrm{m}$ (c) Spektra transmitansi pada struktur

Terlihat dari gambar 15 (b), cahaya terlokalisasi disepanjang defek baris. Penguatan medan pada cacat tersebut menghasilkan transmitansi bernilai satu seperti pada gambar 4 (b) akan tetapi terjadi pergeseran selang band gap menjadi sangat lebar jika dibandingkan dengan spektra transmitansi tanpa defek. Cacat pada tengah struktur mengakibatkan cahaya yang menjalar sepanjang arah $y$ akan terlokalisasi di sepanjang baris cacat kristal pada arah $x$ .dimana gelombang mengalami pemantulan terus-menerus secara harmonik disekitar defeknya.

Panjang gelombang PPB dapat digeser berdasarkan variasi sudut datang dan nilai transmitansinya dapat diatur sesuai dengan indeks bias defek

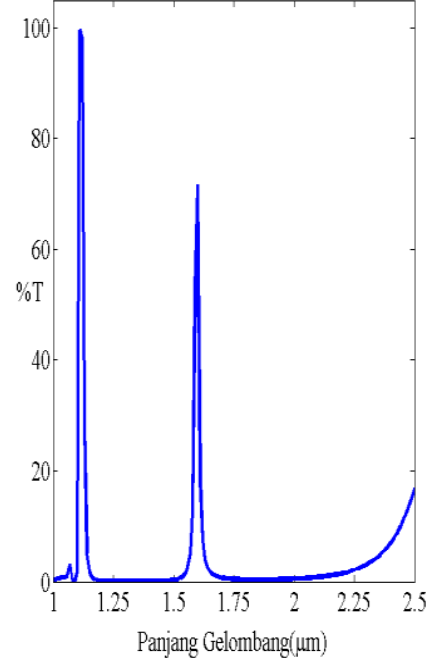

(a)

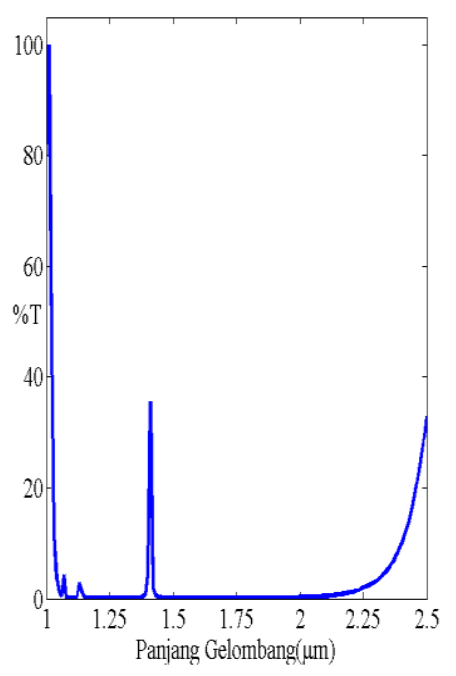

(b)

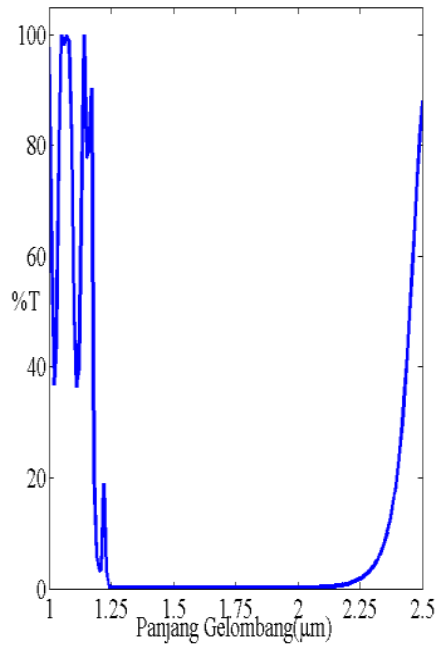

(c)

Gambar 5. Pergeseran range panjang gelombang PPB dengan sudut datang (a) $30^{\circ}$ (b) $45^{\circ}$ dan (c) $60^{\circ}$ 
Sesuai dengan penelitian ssssebelumnya bahwa semakin besar nilai sudut datang dapat menggeser PPB ke arah kiri diiringi dengan penurunan puncak transmitansi, pada sudut $60^{\circ}$ telihat bahwa PPB hilang.

\section{Kesimpulan}

Berdasarkan hasil yang telah didapatkan, bahwa metode FDFD efektif untuk menganalisis interaksi gelombang elektromagnetik terhadap struktur kristal fotonik. Untuk kristal fotonik tanpa defek terlihat munculnya PBG dan range frekuensinya dapat digeser sesuai dengan sudut datang dari gelombang elektromagnetik yang masuk. Untuk kristal fotonik dengan cacat terlihat munculnya PPB dengan puncsknya yang berubah seiring dengan perubahan sudut datang dan besarnya indeks bias defek.

\section{Referensi}

[1] Alatas, H., Mayditia, H., Hardhienata, H., Iskandar, A.A., Tjia, M.O. 2006. Single-frequency refractive index sensor based on a finite one-dimensional photonic crystals with two defects. Japanese Journal of Applied Physics, Part 1: Regular Papers and Short Notes and Review Papers, 45 (8 B), pp. 6754-6758. DOI: 10.1143/JJAP.45.6754

[2] Reddy, JN. 2006. Pengantar Metode Elemen Hingga (edisi ketiga). McGraw-Hill: New-York. ISBN 9780071267618 .

[3] K. S. Yee.1966. Numerical solution of initial boundary value problems involving maxwell's equation in isotropic media. IEEE Trans. Antennas Propag., 14(3),pp. 302-30.

[4] M.L. Lui, Z Cheng.1999. A direct computation of propagation constant using compact 2Dfull-wave eigen-based finite-difference frequency-domain technique Proceedings of the 1999 International Conference on ComputationalElectromagnetics and Its Applications (ICCEA '99), pp. 78-81.

[5] Berenger JP. 1994. A Perfectly Matched Layer (PML) for the Absorption of Electromagnetic Waves. Journal of Computational Physic, 114:185-200.

[6] D.M. Pozar. 2005. Microwave Engineering Third Edition, New York: John Wiley \& Sons, Inc, pp.5-6.

[7] Y. Huang. 2012, Plasmonic Devices for Manipulating Light at The Nanoscale: SlowLightWaveguides and Compact Couplers, Dissertasi, Louisiana State University: Baton

[8] Rauge C. G. Batista, C. G. Rego. 2018. Application of the Finite-Difference FrequencyDomain (FDFD) method on radiowave propagation in urban environments, J. Microw. Optoelectron. Electromagn. Appl. 17(3). 